University of Nebraska - Lincoln

DigitalCommons@University of Nebraska - Lincoln

1989

\title{
Assessment of Squirrel-Caused Power Outages
}

\author{
J. Chris Hamilton \\ University of Nebraska - Lincoln \\ Ron J. Johnson \\ University of Nebraska-Lincoln, ronj@clemson.edu \\ Ronald M. Case \\ University of Nebraska-Lincoln, rcase2@neb.rr.com \\ Michael W. Riley \\ University of Nebraska - Lincoln, mriley1@unl.edu
}

Follow this and additional works at: https://digitalcommons.unl.edu/natrespapers

Part of the Natural Resources and Conservation Commons, Natural Resources Management and Policy Commons, Operations Research, Systems Engineering and Industrial Engineering Commons, Other Electrical and Computer Engineering Commons, and the Other Environmental Sciences Commons

Hamilton, J. Chris; Johnson, Ron J.; Case, Ronald M.; and Riley, Michael W., "Assessment of SquirrelCaused Power Outages" (1989). Papers in Natural Resources. 663.

https://digitalcommons.unl.edu/natrespapers/663

This Article is brought to you for free and open access by the Natural Resources, School of at DigitalCommons@University of Nebraska - Lincoln. It has been accepted for inclusion in Papers in Natural Resources by an authorized administrator of DigitalCommons@University of Nebraska - Lincoln. 


\section{J. Chris Hamilton, ${ }^{1}$ Ron J. Johnson, ${ }^{2}$ Ronald M. Case, ${ }^{3}$ and Michael W. Riley ${ }^{4}$}

\section{Assessment of Squirrel-Caused Power Outages}

REFERENCES: Hamilton, J. C., Johnson, R. J., Case, R. M., and Riley, M. W., “Assessment of Squirrel-Caused Power Outages," in Vertebrate Pest Control and Management Materials: 6th Volume, ASTM STP 1055, Kathleen A. Fagerstone and Richard D. Curnow, Eds,, American Society for Testing and Materials, Philadelphia, 1989, pp. 34-40.

ABSTRACT: Squirrel-caused power outages in Lincoln and Omaha, Nebraska, were evaluated by examining company power outage reports and by consulting with power company representatives. Reports showed that squirrel-caused outages at pole-mounted transformers were most prevalent during May, June, and October ( $48 \%$ of total) and between 1 and $4 \mathrm{~h}$ after sunrise $(38 \%)$, patterns that coincide with squirrel dispersal or morning activity periods. In Lincoln, 1980 and 1981 , squirrels caused 177 outages per year, which was $24 \%$ of all outages and $90 \%$ of animal-caused outages. Estimated minimum annual costs were $\$ 23364$ for repairs, public relations, and lost revenue while meters were not running. In Omaha, 1985 and 1986 , squirrels caused 332 outages per year, costing at least $\$ 47144$ annually. Squirrelcaused outages at substations cost an additional $\$ 400$ (Lincoln) to $\$ 810$ (Omaha) annually. Between 1982 and 1985 , squirrel guards were installed on all 13000 Lincoln transformers at an estimated minimum cost of $\$ 20$ per guard, or $\$ 260000$ total. Records from Lincoln after all guards were installed (1986 and 1987) indicate that annual costs were reduced $78 \%$ to $\$ 5148$. Life expectancy of the guards is unknown. The extent of squirrel-caused outages and associated costs may vary among cities and regions. Assessment of these outages as described here can be used for timing biological studies and as a procedural structure for making similar economic assessments in other areas.

KEY WORDS: vertebrate pest control, fox squirrel, urban wildlife, power distribution equipment, electrical outages, Sciurus niger, wildlife damage

One problem faced by electrical power companies is maintaining an uninterrupted flow of electrical service to their clientele. Power outages result in customer dissatisfaction as well as repair costs and lost revenue while meters are not running. Outages may be caused by weather, equipment failures, and various animals, particularly squirrels (Sciurus spp.) $[1-4]$.

Both fox (S. niger) and gray (S. carolinensis) squirrels use electrical power and telephone equipment as travel lanes and rest sites, or for other activities [1-4]. When a squirrel climbs on an electrical transformer, it may cross the bare, high-voltage wire leading from the high-voltage line to the transformer. If the squirrel simultaneously touches a part of

' Graduate research assistant, Department of Forestry, Fisheries, and Wildlife, University of Nebraska, Lincoln, NE 68583-0819.

2 Extension wildlife specialist and associate professor, Department of Forestry, Fisheries, and Wildlife, University of Nebraska, Lincoln, NE 68583-0819.

${ }^{3}$ Professor, Department of Forestry, Fisheries, and Wildlife, University of Nebraska, Lincoln, NE 68583-0819.

${ }^{4}$ Professor, Department of Industrial and Management Systems Engineering, University of Nebraska, Lincoln, NE 68588-0518. 
the transformer where there is sufficient electrical ground, the result is a power outage and electrocution of the squirrel. The power outage results from an electrical short, which causes a high current flow on the distribution circuit. Normally a fuse opens, and all residents on the circuit (average about 50) lose power. Squirrels may also cause outages at other specific sites on power distribution equipment but not as commonly as at this site on the transformer.

Faced with the problem of squirrel-caused outages, Lincoln Electric System (LES) and Omaha Public Power District (OPPD), after evaluating alternatives, installed squirrel guards, devices that cover the bare high-voltage wire at the point on the transformer where squirrels are electrocuted. In Lincoln, Nebraska, 1982 to 1985, squirrel guards were placed on all 13000 pole-mounted transformers. ${ }^{5}$ In Omaha, Nebraska, 1985 to 1987 , about 3000 squirrel guards were installed on transformers in areas with squirrel problems, and eventually will be placed on all 59000 existing transformers. ${ }^{6}$ However, no in-depth assessment was made of costs associated with these guards in relation to costs associated with squirrelcaused outages.

To understand better squirrel-caused outage problems, information was needed on outage patterns in relation to known squirrel biology. In addition, an assessment of costs associated with such outages was needed to provide economic guidelines helpful in development and use of control techniques. Therefore, our objectives were to compare seasonal and diurnal outage patterns with squirrel biology patterns, and to develop an economic assessment of both repair costs and preventive measures currently being used.

\section{Distribution Equipment}

In Lincoln and Omaha, power distribution equipment includes a transformer and one or two high-voltage cables (for example, $12000 \mathrm{~V}$ ) above the transformer. These highvoltage lines lead, via a fuse, to a transformer where the voltage is reduced to 120 or 240 $\mathrm{V}$ and then distributed through service cables, below the transformer, to surrounding houses (Fig. 1). Because one fuse may protect one or several transformers, an outage at one transformer may blow a fuse and cut power to several. Telephone and cable television cables are below the service cables.

\section{Methods}

Electric company records from Lincoln (January 1980 through December 1987) and Omaha (January 1985 through December 1986) were evaluated to determine the date, time, and location of outages. These years were selected in part because of availability of records from the power companies. The outage records, which showed the number and cause of outages, indicated squirrel-caused outages only when a repair crew found a dead squirrel at the site. Squirrel-caused outages in Lincoln were plotted on a map.

Economic analysis of squirrel-caused outages was based on information from power outage reports and from consultation with power company officials. ${ }^{5,6}$ These estimates included, for both Lincoln and Omaha, costs associated with squirrel-caused power outages at transformers and the costs of squirrel guard installation. The cost per transformer

\footnotetext{
${ }^{5}$ R. E. Reutzel, Supervisor of Systems Control, Lincoln Electric System, Lincoln, NE, personal communiction, 1987.

${ }^{6}$ R. C. O'Neill, Supervisor, Transmission and Distribution, Omaha Public Power District, Omaha, NE, personal communication, 1987.
} 


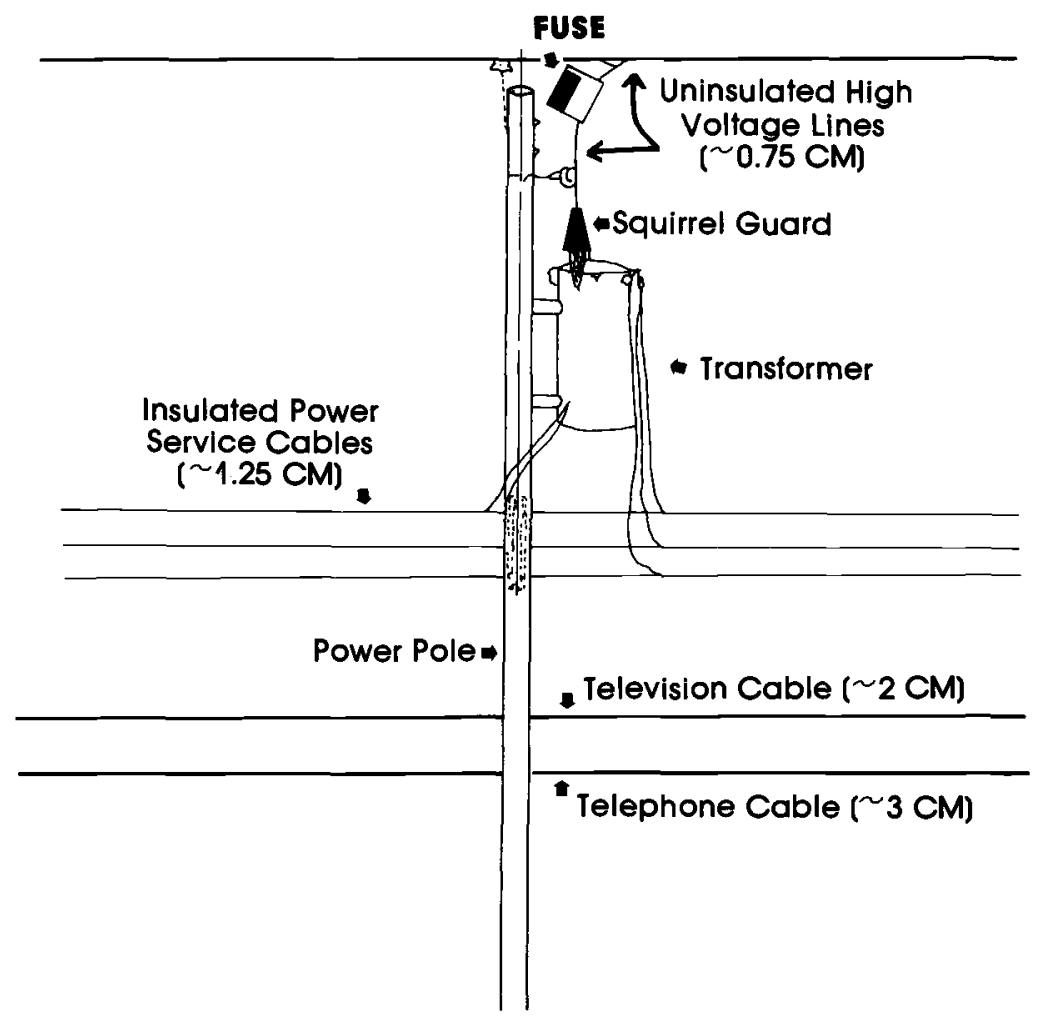

FIG. 1-Power pole arrangement showing an electrical transformer with a squirrel guard installed and various cables with outside diameters indicated.

outage included a repair crew, materials, office personnel, public relations, and lost revenue while meters were not running. Minimum public relations costs, based on customer dissatisfaction, were assumed to be one cent per minute of outage per household. Lost revenue was the average number of kilowatt hours (average kilovolt amperes $\times 0.85 \times$ average length of outages in hours) $\times \$ 0.07$. Additional annual costs included expenses from squirrel-caused substation outages or costs other than those accrued when a fuse was blown at a transformer. Installation of a squirrel guard required expenses for an equipped installation crew and the guard. To determine effectiveness of squirrel guards, outage costs in Lincoln before guards (January 1980 through December 1981) were compared to the costs after guards were installed (January 1986 through December 1987).

\section{Results}

Records of 667 squirrel-caused outages at pole-mounted transformers in Lincoln (1980 to 1987 ) and 664 in Omaha (1985 and 1986) showed that $48 \%$ occurred in May (193), June (243), or October (202), and 38\% (512) occurred between 1 and $4 \mathrm{~h}$ after sunrise (Figs. 2 and 3). Of the May outages, $76 \%$ occurred in the latter half of the month (15 to 31 May). In Lincoln, before guards were installed (1980 and 1981), squirrels caused 177 outages per year, which was $24 \%$ of all outages and $90 \%$ of animal-caused outages. After guard installation (1986 and 1987), squirrel-caused outages averaged 39 per year. In Omaha (1985 and 


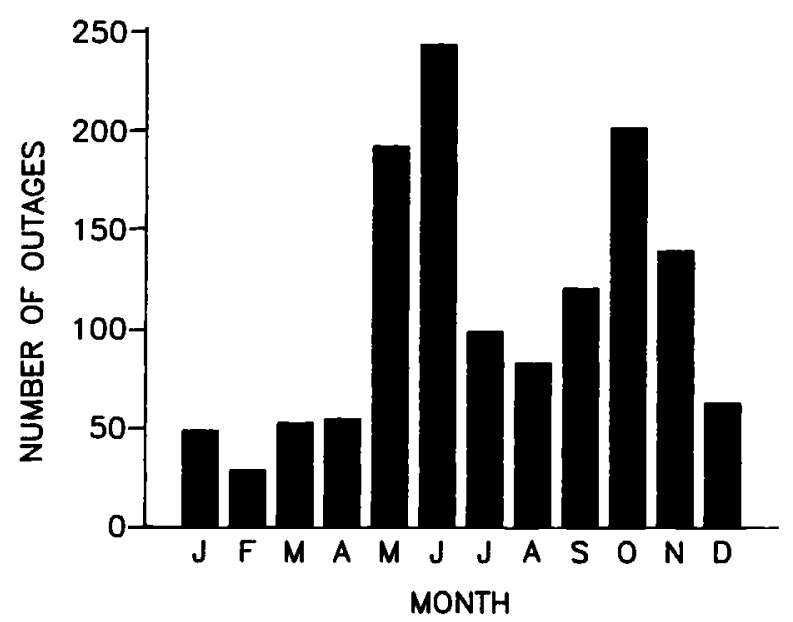

FIG. 2-Number of squirrel-caused power outages by month in Lincoln (1980 through 1987) and Omaha (1985 and 1986), Nebraska.

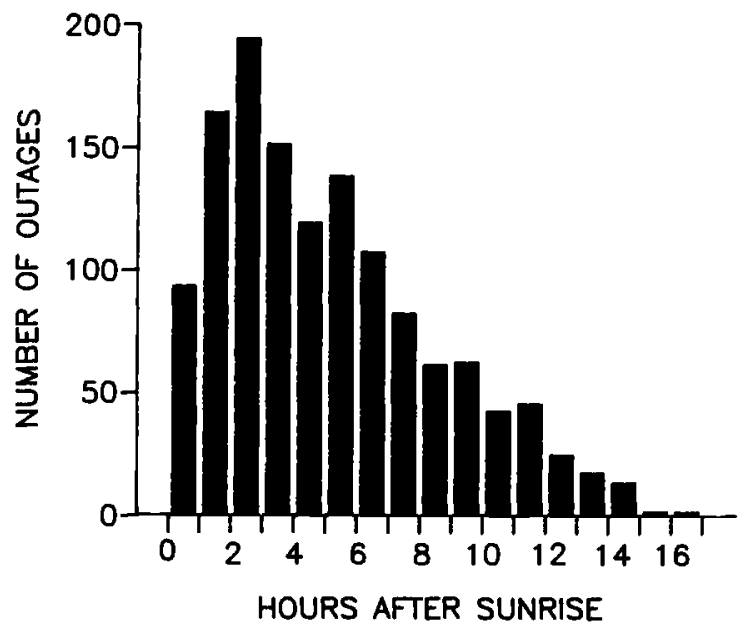

FIG. 3-Number of squirrel-caused power outages by hour after sunrise in Lincoln (1980 through 1987) and Omaha (1985 and 1986), Nebraska.

1986), squirrel-caused outages averaged 332 per year. Average outage length was 60 min in Lincoln and $72 \mathrm{~min}$ in Omaha. Average kilovolt amperes during outages were 290 in Lincoln and 294 in Omaha. In general, transformers with squirrel-caused outages were located in older neighborhoods that had large mast-producing trees.

The average cost per transformer outage was estimated to be $\$ 132$ in Lincoln and $\$ 142$ in Omaha. These estimates include $\$ 50$ for a two-person repair crew ( $1 \mathrm{~h}$ at $\$ 50$ per hour), $\$ 15$ for a fuse, $\$ 20$ for office personnel, $\$ 17$ (Lincoln) or $\$ 21$ (Omaha) for lost revenue during outages, and $\$ 30$ (Lincoln) or $\$ 36$ (Omaha) for public relations costs $(\sim 50$ houses per outage per minute). Total annual costs associated with squirrel-caused outages at transformers were \$23 364 for Lincoln and \$47144 for Omaha. 
In addition to the cost per transformer outage, annual costs included $\$ 400$ for damage to electrical substation equipment in Lincoln and $\$ 810$ for substation repairs in Omaha. Lost revenue and public relations costs associated with these substation outages would be additional. Thus, minimum annual costs associated with squirrel-caused outages in Lincoln (1980 and 1981) and Omaha (1985 and 1986) were \$23 764 and \$47 954, respectively.

Installation of a squirrel guard was estimated to cost $\$ 20$, which included the guard ( $\sim$ \$) and about 20 min labor $(\sim \$ 16)$. Thus, estimated cost for installation of the 13000 guards in Lincoln was $\$ 260000$. The squirrel guards in Lincoln reduced annual costs associated with squirrel-caused outages by $78 \%$ from $\$ 23764$ to $\$ 5148$, or a reduction of $\$ 18616$.

\section{Discussion}

Squirrel-caused power outages represent a substantial problem as indicated by outage repair costs and by the proportion of outages caused by squirrels. Squirrel-caused outages were most prevalent in late May, June, and October and between 1 and $4 \mathrm{~h}$ after sunrise, times that correspond with squirrel biological patterns. May, June, and October follow the two annual squirrel reproductive seasons and are peak months for dispersal of young squirrels [5-7]. Thus, dispersal of young squirrels, which coincides with peak outage periods, may be a biological and behavioral focal point that warrants further study in relation to power outages. A Washington, D.C., analysis indicates November as the peak month for animal-caused outages there, and suggests that this pattern may relate to squirrels retrieving food or other items stored on transformers [2,3]. In their analysis, squirrels accounted for about $16 \%$ of all outages and for $93 \%$ of animal-caused outages, compared to our results of 24 and $90 \%$, respectively. Squirrel-caused outage patterns and biological relationships may vary among areas or regions but also have certain similarities. Outage records from additional locations are needed to establish overall patterns or to clarify the relationships that exist with the squirrel populations involved. Outages were most prevalent during morning hours, especially between 1 and $4 \mathrm{~h}$ after sunrise. This pattern coincides with the daily period of greatest activity for fox and gray squirrels, both urban and rural [8-11]. Overall, understanding outage patterns helps in evaluating the behavioral basis of damage and in focusing biologically based field studies on times when damage is most prevalent.

In general, transformers with squirrel-caused outages were located in older neighborhoods that had large mast-producing oaks (Quercus spp.). Hard-mast producing trees, particularly oaks, are the primary food source for fox squirrels, and populations tend to fluctuate in response to acorn availability [5,8]. In fact, basal area of hard-mast trees has been used in rural areas as an indicator of fox squirrel population size [12]. Although the presence of hard-mast trees indicates availability of a food source, it may not correspond directly with squirrel population levels in urban areas. Moreover, other data show that basal area of hard-mast trees does not distinguish transformer sites with squirrel-caused outages from those without such outages [4]. However, with further study, hard-mast availability might be useful on a larger, city-wide scale to indicate neighborhoods most likely to have threshold numbers of squirrels at which outages become common.

Our results indicate that squirrel-caused outages at transformers cost $\$ 132$ to $\$ 142$ each. During the same time as our study, a Washington, D.C. power company made estimates for similar repairs $[2,3]$. They reported a range of 488 to 1263 (average 653) animal-caused outages per year from July 1983 through December 1987 at a cost of $\$ 242$ per outage [2,3]. Their average of 653 outages per year would cost $\$ 158026$ for repairs. The $\$ 242$ per outage included $\$ 75.20$ for a 1.5 -person repair crew ( $1.6 \mathrm{~h}$ at $\$ 47$ per hour), $\$ 9.50$ for a fuse (average of fuse types), $\$ 1.34$ for lost revenue (based on $1.12 \mathrm{kwh}$ per hour [average use] $\times 1.6$ 
$\mathrm{h}$ [average outage time] $\times \$ 0.0671$ per $\mathrm{kwh} \times 11.1$ homes affected), $\$ 16.34$ for related system maintenance (breaker life: $\$ 14.26$ for labor, $\$ 2.08$ for oil), $\$ 105.12$ for dispatcher personnel (annual salaries and benefits/total outages per year), and $\$ 34.50$ for customer information personnel (annual salaries and benefits/[total outages per year $\times$ four calls per outage] $)^{7}[2]$. This estimate, in comparison with ours, has greater costs for repair time and office personnel (dispatcher and customer information), but less for lost revenue and public relations, although customer information is related to public relations. Costs by category were difficult to quantify precisely [2] and probably vary among companies because of personnel costs, travel time, and other factors. Although the Zellmer et al. estimate differs from ours, each was based on values pertinent to the company and situation. Each approach has points that merit consideration by others considering such assessments.

Squirrel guard installation in Lincoln reduced damage costs by an estimated $\$ 18616$ per year. At a $0 \%$ interest rate, the break-even period for guard installation ( $\$ 260000$ ) would be approximately 14 years. If a conservative $5 \%$ interest rate is used, break-even would be approximately 25 years, assuming the guards last that long. Initial types of squirrel guards, which are no longer used, lasted only about 5 to 6 years, largely because of exposure to ultraviolet rays. Squirrel guards currently installed by two companies ${ }^{8}$ [3] are made of plasticlike polyethylene or rubberlike ethylene propylene and vary in shape and installation features. These are expected to last longer, but their life expectancy is unknown. Because of various tax considerations, the financial burden on the company would probably be less than these amounts and the break-even periods would be shorter. However, costs are still considerable. Various types of squirrel guards appear satisfactory but using them is a relatively new technique. We recommend that guard selection include review of available data and consultation with experienced users.

Public relations is a point of critical concern to power companies ${ }^{5}$ [3] and one that our analysis may underestimate. These costs appear to be the most difficult to quantify and possibly the most likely to vary according to customer needs (including business and other high-use customers, effects on computer data, and so forth), attitudes, and tolerance for outages. The unquantified costs associated with public relations help justify the expense for guards.

Squirrel-caused power outage problems warrant additional attention. Although, squirrel guards reduce damage at transformers, they do not eliminate it, and the costs of guard installation on all transformers may be prohibitive for some companies. Squirrels may cause outages at other sites including at lightning arresters (located on or above transformers), cutouts (switches located above transformers), and at switches located on main feeder lines, ${ }^{9}$ as well as at faulty squirrel guards. Moreover, squirrel-caused outages at substations, although less frequent than on distribution equipment, are usually more costly and may affect considerably more customers. For example, one squirrel-caused substation outage near Washington, D.C. in 1987 resulted in 9000 customers without power for $>30 \mathrm{~h}$ and loss of significant substation equipment. ${ }^{7}$ Additional understanding of squirrels in relation to electrical power equipment, and viable damage control options, are needed.

Evaluation of power company records and consultation with company representatives provided the information needed to assess squirrel-caused outages. However, pertinent

${ }^{7}$ B. J. Zellmer, Transmission and Distribution, Potomac Electric Power Company, Washington, DC, unpublished data.

${ }^{8}$ S. L. Young, Senior Engineer, Distribution, Lincoln Electric System, Lincoln, NE, personal communication, 1988.

${ }_{9}^{9}$ B. J. Zellmer, Transmission and Distribution, Potomac Electric Power Company, Washington, DC, personal communication. 
outage records from some years were not available. We encourage all companies that experience squirrel-caused damage, including power, telephone, and cable television companies, to maintain records of the cause, date, time, specific site, associated costs, and other pertinent information. Only with such records can damage patterns and costs in relation to controls be understood, and cost-effective solutions developed. Moreover, if records were available over many years, outage patterns could be evaluated in relation to squirrel population cycles, size of mast crops, and other variables.

This study has provided, for two Nebraska cities, date and time patterns of squirrelcaused outages and an economic assessment of these outages. Results can be used in developing other biological studies and as a procedural structure for making similar, and needed, economic assessments of the problem in other cities.

\section{Acknowledgments}

We gratefully acknowledge the cooperation and assistance provided by $R$. E. Reutzel of the Lincoln Electric System; R. C. O'Neill, M. E. Naslund, and D. D. Welsh of the Omaha Public Power District; B. J. Zellmer of the Potomac Electric Power Company; and J. G. Fiske of the Rochester Gas and Electric Corporation. Without their help, this study would not have been possible. We also thank M. M. Beck, R. C. O'Neill, R. E. Reutzel, and J. A. Savidge for reviewing the manuscript.

\section{References}

[I] "Squirrels Blacking Out Washington DC," National Wildlife, Vol. 23, No. 2, 1985, p. 32.

[2] "Animal Outage Report 1987," Potomac Electric Power Co., Washington, DC, 1988.

[3] Zellmer, B., Schwab, J., Diez, M., Alongi, T., and DeGuistino, D., "Final Report of the T\&D Animal Outage Task Force," Potomac Electric Power Company, Washington, DC, 1986.

[4] Hamilton, J. C., "Fox Squirrel Interaction with Electrical Transformers," M.S. thesis, University of Nebraska, Lincoln, NE, 1987.

[5] Allen, D. L., Michigan Fox Squirrel Management, Michigan Department of Conservation, Lansing, MI, No. 100, 1943.

[6] Thompson, D. C., "The Social System of the Grey Squirrel," Behaviour, Vol. 64, 1978, pp. 305328.

[7] Schwartz, C. W. and Schwartz, E. R., The Wild Mammals of Missouri. Rev. ed., University of Missouri Press and Missouri Department of Conservation, 1981.

[8] Brown, L. G. and Yeager, L. E., Fox Squirrels and Gray Squirrels in Illinois, Natural History Survey Bulletin, No. 23, 1945, pp. 449-536.

[9] Fogl, J. G., "Ecology of Melanistic Gray Squirrels and Fox Squirrels in an Urban Area," Ph.D. dissertation, Michigan State University, East Lansing, 1982.

[10[ Hicks, E. A., "Ecological Factors Affecting the Activity of the Western Fox Squirrel (Geoffry)," Ecological Monographs, Vol. 19, 1949, pp. 289-302.

[11] Manski, D. A., Vandruff, L. W., and Flyger, V., "Activities of Gray Squirrels and People in a Downtown Washington, DC, Park: Management Implications," Transactions of the North American Wildlife and Natural Resources Conference, Vol. 46, 1981, pp. 439-454.

[12] Nixon, C. M., McClain, M. W., and Donahoe, R. W., "Effects of Hunting and Mast Crops on a Squirrel Population," Journal of Wildlife Management, Vol. 39, No. 1, 1975, pp. 1-25. 